\title{
Polytetrafluorethylene Added to Acrylic Resins: Mechanical Properties
}

\author{
Fabiana Gouveia STRAIOTO ${ }^{1}$ \\ Antonio Pedro RICOMINI FILHO ${ }^{1}$ \\ Alfredo Júlio FERNANDES NETO ${ }^{2}$ \\ Altair Antoninha DEL BEL CURY ${ }^{1}$ \\ ${ }^{1}$ Department of Prosthodontics and Periodontology, Piracicaba Dental School, \\ State University of Campinas, Piracicaba, SP, Brazil \\ ${ }^{2}$ Department of Occlusion, Fixed Prosthodontics and Dental Materials, \\ Federal University of Uberlândia, Uberlândia, $M G$, Brazil
}

\begin{abstract}
The addition of different polymers, such as polytetrafluorethylene (PTFE), to denture base resins could be an option to modify acrylic resin mechanical properties. This study evaluated the surface hardness, impact and flexural strength, flexural modulus and peak load of 2 acrylic resins, one subjected to a long and another subjected to a short polymerization cycle, which were prepared with or without the addition of $2 \%$ PTFE. Four groups were formed according to the polymerization cycle and addition or not of PTFE. Forty specimens were prepared for each test (10 per group) with the following dimensions: hardness (30 mm diameter x $5 \mathrm{~mm}$ thick), impact strength $(50 \times 6 \times 4 \mathrm{~mm})$ and flexural strength $(64 \times 10 \times 3.3 \mathrm{~mm})$ test. The results of the flexural strength test allowed calculating flexural modulus and peak of load values. All tests were performed in accordance with the ISO 1567:1999 standard. Data were analyzed statistically by ANOVA and Tukey's test with the level of significance set at $5 \%$. No statistically significant differences ( $p>0.05)$ were found for surface hardness. Flexural strength, impact strength and peak load were significantly higher $(p<0.05)$ for resins without added PTFE. The flexural modulus of the acrylic resin with incorporated 2\% PTFE polymerized by long cycle was significantly higher $(p<0.05)$ than that of the other resins. Within the limits of this study, it may be concluded that the addition of PTFE did not improve the mechanical properties of the evaluated acrylic resins.
\end{abstract}

Key Words: acrylic resin, polytetrafluoroethylene, surface hardness, impact strength and flexural strength.

\section{INTRODUCTION}

Acrylic resins have been used for a long time as the best choice to fabricate full or partial dentures because of its esthetic qualities and ease of manipulation. Nevertheless, their mechanical properties should be improved (1). This material is also a potential substrate for biofilm formation, and is responsible for the development of denture stomatitis (2).

Alternatives to improve the mechanical properties of acrylic resins have been described, and include the addition of copolymers, cross-linking agents (3-6) and rubber substances in the form of butadiene styrene (7). The use of the phosphate-containing monomer ethylene glycol dimethacrylate as substitute for the methyl meth- acrylate monomer to reduce microorganism colonization has also been described (8). However, the addition of synthetic fluoropolymers, such as polytetrafluorethylene (PTFE) particles, to the polymeric matrix of acrylic resin in order to control microorganism adhesion, avoid unwanted creep and improve wear and friction is still unexplored. Although little information is available about the use of PTFE for dental applications $(9,10)$, it is known that PTFE is chemically inert, biocompatible, highly resistance to chemical reagents, and has high temperature tolerance, low surface energy and low coefficient of friction, which allows this material to act as a sealing and lubricant pellicle (11).

Considering PTFE characteristics, the addition of this synthetic fluoropolymer to methyl methacrylate

Correspondence: Profa. Dra. Altair Antoninha Del Bel Cury, Departamento de Prótese e Periodontia, Faculdade de Odontologia de Piracicaba, Universidade de Campinas, CP 52, 13414-903 Piracicaba, SP, Brasil. Tel: +55-19-2106-5294. Fax: +55-19-2106-5211. e-mail: altcury@fop.unicamp.br 
might improve its surface properties, decreasing surface wetting and surface free energy, and consequently modifying microbial adhesion, as well as slowing acrylic resin degradation in the oral environment. However, changes in the composition of acrylic resins should not compromise the mechanical properties of this material. Impact and flexural strength are the two most important mechanical properties of denture base resins (8). Impact strength gives the required resistance to fracture when a denture is accidentally dropped onto a hard surface, and flexural strength is responsible for giving resistance to fracture under dynamic load $(4,7,8)$. In addition, hardness is a relevant surface characteristic and represents resistance to scratching, abrasion or cutting material. This characteristic is related to the material wear that can take place during daily denture brushing causing roughness, and facilitating microbial adhesion (12). Indeed, few studies have addressed the physical and mechanical proprieties of acrylic resins modified by PTFE (13).

The aim of this study was to evaluate surface hardness, impact and flexural strength, flexural modulus and peak of load of 2 acrylic resins modified by the addition of $2 \%$ PTFE.

\section{MATERIAL AND METHODS}

The materials used in this study are shown in Table 1. Two acrylic resins, one subjected to a long and another subjected to a short polymerization cycle, which were prepared with or without the incorporation of $2 \%$ PTFE powder (wt $/ \mathrm{wt}$ ) were used to fabricate the specimens. These acrylic resins were chosen because the two cycles are the most commonly used in commercial laboratories.

Four groups were formed according to the polymerization cycle and addition or not of PTFE: LC: acrylic resin polymerized by long cycle; LE: acrylic resin plus $2 \%$ PTFE polymerized by long cycle; SC: acrylic resin polymerized by short cycle; and SE: acrylic resin plus $2 \%$ PTFE polymerized by short cycle. Forty specimens were prepared for each test, being 10 specimens for each group with the following dimensions: hardness (30 mm diameter $\times 5 \mathrm{~mm}$ thick), impact strength ( $50 \times 6 \times 4 \mathrm{~mm})$ and flexural strength $(64 \times 10 \times 3.3 \mathrm{~mm})$ test. The results of the flexural strength test allowed calculating flexural modulus and peak of load values $(1,14)$.

Metal master patterns were individually invested with high-viscosity silicone (Zetalabor; Zermack S.p.A, Badia Polesine, Rovigo, Italy) and used to fabricate the specimens (15). Patterns were invested with Type III dental stone (Herodent Soli Rock; Rio de Janeiro, RJ, Brazil) in metallic dental flasks (Uraby; DLC, São Paulo, SP, Brazil). Each acrylic resin polymer was mixed with $2 \%$ of PTFE $(\mathrm{w} / \mathrm{w})$, then the monomer was added in accordance with the manufacturers' instructions, and the mixture was packed into the silicone mold at the dough stage.

For the resin (with and without PTFE) polymerized by long cycle, all flasks were placed in a polymerizing unit (Termotron P-100; Termotron Equipamentos Ltd, Piracicaba, SP, Brazil) filled with water at $74^{\circ} \mathrm{C}$ for $9 \mathrm{~h}$. For the resin (with and without PTFE) polymerized

Table 1. Acrylic resins and polytetrafluorethylene used in this study.

\begin{tabular}{|c|c|c|c|}
\hline Material & Processing method & Chemical composition & Manufacturer \\
\hline Polymethyl methacrylate & $\begin{array}{l}\text { Hot water bath } \\
9 \mathrm{~h} \text { at } 74^{\circ} \mathrm{C}\end{array}$ & $\begin{array}{l}\text { Powder: Poly methyl methacrylate, ethylacrylate, } \\
\text { benzoyl peroxide, organic pigments }\end{array}$ & $\begin{array}{l}\text { Classico Ind. e Com, } \\
\text { São Paulo, SP, Brazil }\end{array}$ \\
\hline \multirow{3}{*}{ Polymethyl methacrylate } & & Liquid: Methyl methacrylate, topanol stabilizer & \multirow{3}{*}{$\begin{array}{l}\text { Dentsply International, } \\
\text { York, PA, USA }\end{array}$} \\
\hline & $\begin{array}{l}\text { Hot water bath } \\
20 \text { min at } 100^{\circ} \mathrm{C}\end{array}$ & $\begin{array}{l}\text { Powder: Copolymer (methyl-n- butyl) } \\
\text { methacrylate, benzoyl peroxide, mineral dyes }\end{array}$ & \\
\hline & & $\begin{array}{l}\text { Liquid: Methylmethacrylate, ethyleneglycol, } \\
\text { dimethacrylate, N,N dimethyl-p-toluidine, } \\
\text { hydroquinone methyl ether }\end{array}$ & \\
\hline Polytetrafluorethylene & ------ & Powder: polytetrafluoroethylene & $\begin{array}{l}\text { Uniflon Fluormasters, } \\
\text { São Paulo, SP, Brazil }\end{array}$ \\
\hline
\end{tabular}


by short polymerization cycle, the flasks were immersed in boiling water for $20 \mathrm{~min}$. After the short and long cycles, the flasks were allowed to bench cool for $2 \mathrm{~h}$, then opened, and the specimens were finished using progressively smoother 320-, 400- and 600-grit aluminum oxide papers in a horizontal polisher (Arotec APL-4; São Paulo, SP, Brazil). Subsequently, polishing of the specimen surfaces to be evaluated for surface hardness was completed on a bench lathe (P134R; Nevone, São Paulo, SP, Brazil) with a roller brush, pumice stone paste (Herjos lot 05794; Probem, São Paulo, SP, Brazil) and water for $15 \mathrm{~s}$, followed by wet polishing wheel and a chalk (Probem) and water slurry for $15 \mathrm{~s}$ followed by a polishing machine with diamond paste (Extec Corp, Enfild, CT, USA) and a cotton disk (Extec). After finishing procedures, the specimens were ultrasonicated (Thornton T 740; Thornton-Inpec Eletronica LTDA, Vinhedo, SP, Brazil) for $20 \mathrm{~min}$ and then immersed in distilled water at $37^{\circ} \mathrm{C}$ for $48 \pm 2 \mathrm{~h}$.

Surface hardness ( $\mathrm{SH})$ of the acrylic resin discs (Ø $30 \times 5 \mathrm{~mm}$ ) was measured with a microhardness tester (Shimadzu HMV-2000, Kyoto, Japan), using a Knoop indenter with a $25 \mathrm{~g}$ load for $5 \mathrm{~s}$. Fifteen indentations were made on each specimen at a distance of $300 \mu \mathrm{m}$ between them and the average of these measurements was considered the microhardness value for the specimen $\left(\mathrm{kg} / \mathrm{mm}^{2}\right)(15-18)$.

The impact strength test was performed according to ISO Standard 1567:1999/Amd.1:2003(E) $(5,19)$, using an impact test machine (AIC - EMIC, São José dos Pinhais, PR, Brazil) by the Charpy method with a pendulum of $0.5 \mathrm{~J}$, in which the specimens were horizontally positioned with a distance of $40 \mathrm{~mm}$ between the 2 fixed supports.

Flexural characteristics, such as flexural strength (MPa), flexural modulus ( $\mathrm{MPa}$ ) and peak load $(\mathrm{N})$, were determined by the 3-point bending test using a universal testing machine (Instron Model 4467; Instron Industrial Products, Grove City, PA, USA) calibrated with a 500 $\mathrm{kgf}$ load cell and a crosshead speed of $5 \mathrm{~mm} / \mathrm{min}$. The flexural testing device consisted of a central loading plunger and 2 polished cylindrical supports, $3.2 \mathrm{~mm}$ in diameter and $10.5 \mathrm{~mm}$ long (19). The distance between the centers of the supports was $50 \mathrm{~mm}$. The compressive force was applied perpendicular to the center of the specimens until fracture occurred $(1,3,7,19,20)$.

Statistical analysis was performed with SAS software (SAS Institute Inc., version 9.0, Cary, NC, USA) using a level of significance fixed at $5 \%$. ANOVA was used to test the null hypothesis that assumed there were no differences among the groups with or without PTFE. Data that violated the assumptions of equality of variances and normal distribution of errors were transformed. The flexural strength was transformed by square root and all data were analyzed by two-way ANOVA and Tukey's post-hoc test.

\section{RESULTS}

Two-way ANOVA indicated significant differences for impact and flexural strength $(\mathrm{p}<0.05)$, but not for surface hardness $(p>0.05)$. Surface hardness showed no statistically significant differences $(p>0.05)$ among the groups $\left(\mathrm{LC}=20.4 \mathrm{~kg} / \mathrm{mm}^{2} \pm 0.35, \mathrm{SC}=20.5 \mathrm{~kg} / \mathrm{mm}^{2} \pm\right.$ $0.33, \mathrm{LE}=20.2 \mathrm{~kg} / \mathrm{mm}^{2} \pm 0.24 ; \mathrm{SE}=20.5 \mathrm{~kg} / \mathrm{mm}^{2} \pm 0.43$ ).

The mean values and standard deviations for impact and flexural strength, flexural modulus and peak load are presented in Table 2.

All materials evaluated with regard to impact strength fulfilled the requirements of ISO 1567 standard $\left(>2 \mathrm{~kJ} / \mathrm{m}^{2}\right)$. However, the impact strength values for the short cycle resin with $2 \%$ PTFE were significantly lower $(p<0.049)$ than those of the other groups.

Flexural strength of LE and SE was significantly

Table 2. Impact strength, flexural strength, flexural modulus and peak load values (Mean \pm SD) obtained in each group ( $\mathrm{n}=10$ ).

\begin{tabular}{lcccc}
\hline Group & Impact strength $\left(\mathrm{kJ} / \mathrm{m}^{2}\right)$ & Flexural strength $(\mathrm{MPa})$ & Flexural modulus $(\mathrm{MPa})$ & Peak load $(\mathrm{N})$ \\
\hline LC (long cycle) & $6.1 \pm 0.5 \mathrm{a}$ & $86.8 \pm 3.5 \mathrm{a}$ & $1895.0 \pm 83.1 \mathrm{a}$ & $137.7 \pm 11.9 \mathrm{a}$ \\
LE (PTFE + long cycle) & $4.3 \pm 1.0 \mathrm{~b}$ & $65.6 \pm 7.5 \mathrm{~b}$ & $2121.5 \pm 67.9 \mathrm{~b}$ & $78.3 \pm 8.5 \mathrm{~b}$ \\
SC (short cycle) & $6.1 \pm 0.6 \mathrm{a}$ & $91.8 \pm 4.1 \mathrm{a}$ & $1822.8 \pm 48.7 \mathrm{a}$ & $116.0 \pm 10.1 \mathrm{c}$ \\
SE (PTFE + short cycle) & $3.3 \pm 0.9 \mathrm{c}$ & $68.2 \pm 7.2 \mathrm{~b}$ & $1795.4 \pm 128.2 \mathrm{a}$ & $84.9 \pm 12.0 \mathrm{~b}$ \\
\hline
\end{tabular}

Different letters indicate statistically differences among acrylic resins (Tukey's test, $\mathrm{p}<0.05$ ). 
lower $(\mathrm{p}<0.05)$ than that of LC and SC. Significantly higher flexural modulus $(\mathrm{p}<0.0001)$ was obtained for LE when compared with the other groups.

There was a general trend towards decreasing peak load values in the groups with the addition of PTFE, and the LC group exhibited higher peak load (N) in comparison with the other groups (Table 2).

\section{DISCUSSION}

The addition of PTFE powder to acrylic resins in order to change its surface characteristic to avoid microorganism adhesion might cause deleterious effects on their mechanical properties.

The surface hardness results showed that the addition of PTFE to the resins polymerized by either a long or a short cycle did not cause any change in this property.

On the other hand, the addition of PTFE to acrylic resins decreased the impact and flexural strengths of the resins, although the obtained values were in accordance with the ISO 1567:1999 standard requirements. These results could be explained by the fact that the resin/ PTFE mixture probably did not resulted in a homogeneous formulation (11). A primary obstacle to achieving substantially complete and thorough distribution of a fine PTFE powder throughout the resin has been recognized because of blending difficulties. This can be explained by the fact that PTFE presents extreme chemical and thermal stability, very high molecular weight and consequently an extremely high melt viscosity and negligible solubility (10). Thus, the PTFE powder was probably not totally incorporated into the polymeric matrix in a homogeneous manner. Thus, the PTFE could act as a barrier that did not allow the product obtained to react homogeneously during the impact and flexural strength tests. Therefore, under tensile stress, or even an impact force, the acrylic resin with incorporated PTFE elongates and breaks under a lower load in comparison with acrylic resin without any PTFE added.

Although the strengths obtained in the groups with PTFE were lower than those of the groups without PTFE, the values are still fulfilled ISO:1567 standard, which recommends values $\geq 2 \mathrm{~kJ} / \mathrm{m}^{2}$ for impact strength and $\geq 65 \mathrm{MPa}$ for flexural strength.

The improvement in flexural modulus is important because it reflects the rigidity of the denture base acrylic resin and assures the integrity of the supporting ridge and tissue $(1,4,19)$. In this study, the long cycle resin with added PTFE obtained the highest value $(2121.5 \pm 67.9 \mathrm{MPa})$ showing that this property was the only one affected by the PTFE. This result could be due to the highly cross-linked polymer structure. It can be assumed that the presence of PTFE powder in the acrylic resin polymerized by long cycle improved its rigidity. This result could be due to the long polymerization cycle being better able to a reach higher temperature affecting the melting point of the PTFE and its initial linking to the polymer network microstructure, whereas the same result was not observed for the peak load, which was the highest recorded $(138 \pm 12 \mathrm{~N})$ in the long cycle group without addition of PTFE $(p<0.05)$. Although the groups with addition of PTFE powder showed the lowest values, they could not be considered unacceptable since the mean peak load of acrylic resin should not be less than $55 \mathrm{~N}$.

Furthermore, one limitation of the present study was that only the addition of $2 \%$ of PTFE was tested. Further research is needed involving the incorporation of different percentages and methods of incorporating the PTFE powder into acrylic resin, as well as, to develop studies focused on longer polymerization cycles and higher polymerization temperatures. In addition, future studies should investigate the surface properties related to the adhesion of microorganisms and biofilm development.

In conclusion, the addition of PTFE powder did not improve the mechanical properties of the evaluated acrylic resins studied. However, the values obtained for all properties were in accordance with the ISO: 1567 standard requirements.

\section{RESUMO}

A adição de diferentes polímeros como o politetrafluoretileno (PTFE) às resinas para base de próteses removíveis pode ser uma opção para modificar as propriedades mecânicas das resinas acrílicas. Este estudo avaliou a dureza de superfície, a resistência ao impacto e à flexão, o módulo flexural e a carga de ruptura de duas resinas acrílicas, uma submetida ao ciclo longo e a outra ao ciclo curto de polimerização, as quais foram preparadas com ou sem a adição de PTFE a $2 \%$. Quatro grupos foram formados de acordo com os ciclos de polimerização e a adição ou não de PTFE. Quarenta espécimes foram preparados para cada teste (10 espécimes por grupo) com as seguintes dimensões: dureza de superfície (30 mm diametro x $5 \mathrm{~mm}$ espessura), resistência ao impacto $(50 \times 6 \times 4 \mathrm{~mm})$, resistência à flexão $(64$ × $10 \times 3,3$ $\mathrm{mm})$. O módulo flexural e a carga de ruptura foram calculados a partir dos valores obtidos no teste de resistência à flexão. Todos os testes foram realizados em conformidade com a Norma ISO 
1567:1999. Os dados foram submetidos à análise de variância e teste de Tukey com nível de significância de 5\%. Não foram encontradas diferenças estatisticamente significantes $(p>0,05)$ para dureza de superfície. Os valores de resistência à flexão, resistência ao impacto e carga de ruptura foram maiores para as resinas sem a adição de PTFE ( $p<0,05)$. O valor do módulo flexural da resina acrílica com adição de PTFE a $2 \%$, polimerizada por ciclo longo, foi maior do que as outras resinas $(p<0,05)$. Dentro das limitações deste estudo, pode-se concluir que a adição de politetrafluoretileno não melhorou as propriedades mecânicas das resinas acrílicas avaliadas.

\section{ACKNOWLEDGEMENTS}

The authors would like to thank to the São Paulo Research Foundation (2006/03090-7) for the scholarship granted to the first author.

\section{REFERENCES}

1. John J, Gangadhar SA, Shah I. Flexural strength of heat-polymerized polymethyl methacrylate denture resin reinforced with glass, aramid, or nylon fibers. J Prosthet Dent 2001;86:424-427.

2. Radford DR, Sweet SP, Challacombe SJ, Walter JD. Adherence of Candida albicans to denture-base materials with different surface finishes. J Dent 1998;26:577-583.

3. Uzun G, Hersek N. Comparison of the fracture resistance of six denture base acrylic resins. J Biomater Appl 2002;17:19-29.

4. Zappini G, Kammann A, Wachter W. Comparison of fracture tests of denture base materials. J Prosthet Dent 2003;90:578-585.

5. Faot F, Costa MA, Del Bel Cury AA, Rodrigues Garcia RC. Impact strength and fracture morphology of denture acrylic resins. J Prosthet Dent 2006;96:367-373.

6. Faot F, Panza LH, Garcia RC, Cury AA. Impact and flexural strength, and fracture morphology of acrylic resins with impact modifiers. Open Dent J 2009;3:137-143.

7. Jagger DC, Jagger RG, Allen SM, Harrison A. An investigation into the transverse and impact strength of "high strength" denture base acrylic resins. J Oral Rehabil 2002;29:263-267.

8. Puri G, Berzins DW, Dhuru VB, Raj PA, Rambhia SK, Dhir G, et al.. Effect of phosphate group addition on the properties of denture base resins. J Prosthet Dent 2008;100:302-308.
9. Gu GZZ, Dang H, Wu Z. Preparation of hydrophobic thin films based on PTFE/acrylic resin/SiO2 complex. J Mater Sci Mater 2004;39:5613-5615.

10. Borkar SGB, Dirmyer M, Delicado R, Sen A, Jackson BR, Badding JV. Polytetrafluoroethylene nano/microfibers by jet blowing. Polymer 2006; 47:8337-8343.

11. Khan MSLD, Heinrich G, Gohs U, Franke R. Structure-property effects on mechanical, friction and wear properties of electron modified PTFE filled EPDM composite. Express Polymer Letters 2009;266:39-48

12. Morgan TD, Wilson M. The effects of surface roughness and type of denture acrylic on biofilm formation by Streptococcus oralis in a constant depth film fermentor. J Appl Microbiol 2001;91:47-53.

13. Chevallier P, Janvier R, Mantovani D, Laroche G. In vitro biological performances of phosphorylcholine-grafted ePTFE prostheses through RFGD plasma techniques. Macromol Biosci 2005;16:829839.

14. Vallittu PK, Lassila VP, Lappalainen R. Acrylic resin-fiber composite-Part I: The effect of fiber concentration on fracture resistance. J Prosthet Dent 1994;71:607-612.

15. Del Bel Cury AA, Rached RN, Ganzarolli SM. Microwave-cured acrylic resins and silicone-gypsum moulding technique. J Oral Rehabil 2001;28:433-438.

16. Oliveira VM, Leon BL, Del Bel Cury AA, Consani S. Influence of number and position of flasks in the monomer release, Knoop hardness and porosity of a microwave-cured acrylic resin. J Oral Rehabil 2003;30:1104-1108.

17. Rodrigues GRC, Joane Augusto de S Jr., Rached RN, Del Bel Cury AA. Effect of denture cleansers on the surface roughness and hardness of a microwave-cured acrylic resin and dental alloys. J Prosthodont 2004;13:173-178.

18. da Silva WJ, Rached RN, Rosalen PL, Del Bel Cury AA. Effects of nystatin, fluconazole and propolis on poly (methyl methacrylate) resin surface. Braz Dent J 2008;19:190-196.

19. Pfeiffer P, Rolleke C, Sherif L. Flexural strength and moduli of hypoallergenic denture base materials. J Prosthet Dent 2005;93:372 377.

20. Jagger DC, Alshumailin YR, Harrison A, Rees JS. The effect of the addition of poly (methyl methacrylate) fibres on the transverse strength of repaired heat-cured acrylic resin. J Oral Rehabil 2003;30:903-908. 